\title{
WACANA KUASA DALAM MITOS PADI DI DALAM GEGURITAN SRI SEDANA
}

\author{
Oleh: \\ Ida Bagus Ngurah \\ gusngurah1988@gmail.com \\ Universitas Mahasaraswati \\ Denpasar
}

Proses Review 5-15 April, Dinyatakan Lolos 20 April

\begin{abstract}
Historically, sexuality was originally a cultural strategy for the division of labor, for example, domestic labor in care. After the rapid development in the next period it turned to be exploitative, from which regulations of the duties related sex have been produced. It then has been developing from the liability of caring and responsibility of carrying out duties to necessity and compliance. This reduction is also noted in various myths that have developed in society, one of which is the myth of rice. This article examines the discourse of power in the rice myth in Geguritan Sri Sedana. Having elaborated the data, it is found that the myth of the emergence of rice with the figures of Goddes Sri and God Siwa, as the main characters in which has an unequal power relationship and assumptions of gender and sexual ideology. The gender ideology reveals the existence of a social difference between the roles of men and women in social life where the position of men is considered higher in the social life. Meanwhile, the ideology of sex reveals the existence of an eternal tyranny of the construction of women as intuitive creatures while men as rational beings.
\end{abstract}

Keywords: Discourse, Power, Myths of Rice

\begin{abstract}
Abstrak
Secara historis, seksualitas pada awalnya merupakan strategi budaya guna pembagian kerja, misalnya, tenaga domestik dalam pengasuhan. Setelah perkembangan pesat dalam masa berikutnya beralih bersifat eksploitatif, dari terdapat penaturalan terhadap tugas-tugas jenis kelamin. Dari keiklasan dalam melaksanakan tugas menjadi keharusan dan kepatuhan. Reduksi ini juga dicatat dalam berbagai mitos yang berkembang di masyarakat salah satunya adalah mitos padi. Artikel ini mengkaji tentang wacana kuasa dalam mitos padi dalam Geguritan Sri Sedana. Setelah analisis data, ditemukan bahwa mitos munculnya padi dengan tokoh Dewi Sri dan Dewa Siwa sebagai tokoh utama memiliki suatu relasi kekuasaan yang timpang dimana terdapat asumsi ideologi gender dan
\end{abstract}


ideologi seks. Ideologi gender mengungkapkan adanya suatu perbedaan sosial peran laki-laki dan perempuan dalam kehidupan sosial dimana kedudukan laki-laki lebih tinggi dalam kehidupan sosial. Sedangkan ideologi seks mengungkapkan adanya suatu tirani abadi terhadap konstruksi perempuan sebagai mahluk intuitif sedangkan laki-laki sebagai mahluk rasional.

Kata kunci: Wacana, Kuasa, Mitos Padi

\section{PENDAHULUAN}

Konsepsi seksualitas sejak jaman Yunani klasik sampai era kontemporer tidak lepas dari wacana yang seksis. Menentukan menjadi lakilaki yang baik dan benar berikut menjadi perempuan yang terhormat di masyarakat tidak lepas dari interaksi sosial, bahkan dapat menimbulkan wacana kekuasaan. Kode biologis yang pertama (laki-laki) dalam rentang sejarah klasik sampai modern hampir diseluruh dunia dicatat mendapatkan tempat yang istimewa dalam adat, agama dan institusi sosial sebelum meletusnya wacana feminisme (perjuangan perempuan dalam menuntut kesetaraan posisi sosial) di Negara-Negara Industrial.

Perkembangan ilmu pengetahuan seturut perubahan sosial yang menjadi akibatnya menjadi biang kerok munculnya wacana feminisme yang mampu merekonstruksi wacana seksualitas di masyarakat dalam bentuk praksis (protes, demonstrasi, dan wacana tandingan), artinya narasi kelaki-lakian dan keperempuanan bergeser dari kodrat menjadi relasional.

Menurut Ritzer dan Goodman, ${ }^{1}$ dimana wanita tidak berperan disektor publik (bekerja), hal tersebut bukan karena keterbatasan kemampuan atau perhatian mereka tetapi karena ada upaya sengaja untuk mengucilkan mereka. Lebih lanjut feminisme dapat dipahami sebagai kajian sekaligus metodologi, hal tersebut sesuai dengan gagasan Arivia $^{2}$ feminisme bertujuan untuk mengungkapkan dalam realita sosial, budaya, politik dimana terdapat ketimpangan, yaitu ketertindasan perempuan dan stereotip yang tidak benar.

Kongkritnya perempuan yang memiliki

1 Ritzar, George dan Goodman Douglas, J. 2004. Teori Sosiologi Modern. Jakarta : Prenada Media.

2 Arivia, Gadis. 2003. Filsafat Berperspektif Feminis. Jakarta: Yayasan Jurnal Perempuan. vagina pada masa pra-pergerakan feminis dianggap baik dan benar sesuai kodratnya dengan perangai lemah lembut, penurut, perawan, aseksual dan pengasuh kepada walinya dalam hal ini laki-laki. Sebaliknya lakilaki dengan slogan Macho haruslah kuat, berwibawa, pembimbing, insan seks dan pemimpin kelaurga, tidak lagi menjadi rujukan.

Namun, tidak serta merta wacana ini dihargai sebagai cara pandang baru tentang seksualitas, terdapat kontra wacana yang datang dari adat, agama bahkan perempuan itu sendiri yang telah menganggap karakteristik perempuan yang dikodratnya sebagai sesuatu yang esensial. Gambaran perempuan dalam mitos, fabel, kesusastraan agama menjadi penguat sikap romantisme tentang seksualitas. Mitos dalam wacana romantis seksualitas memberikan gambaran utopis yang dianggap memberikan keteraturan.

Kata mitos berasal dari bahasa Yunani muthos yang secara harfiah diartikan sebagai cerita atau sesuatu yang dikatakan seseorang, secara lebih luas berarti pernyataan, sebuah cerita, ataupun alur suatu drama ${ }^{3}$. Terkait dengan penulisan ini konsep mitos dimengerti sebagai sebuah cerita yang melibatkan tokoh-tokoh mistik seperti Dewa, Raksasa, guna mengungkapkan kejadian, asal-usul sesuatu hal. Salah satu mitos yang menggambarkan pengkondisian seksual yang bernuansa romantik adalah mitos Dewi Sri atau Dewi Padi. Mitos Dewi Sri merupakan suatu cerita mistik mengenai awal mula munculnya tanaman padi di Bumi.

\section{PEMBAHASAN}

\subsection{Sinopsis Mitos Kemunculan Padi}

Sinopsis dalam tulisan ini diuraikan untuk mengetahui gambaran umum cerita dalam

3 Mariasusai Dhavamony. 1995. Fenomenologi Agama. Yogyakarta: Kanisius 
Geguritan Sri Sedana. Secara garis besar cerita dalam Geguritan Sri Sedana mengisahkan prihal mitologi timbulnya tanaman padi. Cerita dalam Geguritan Sri Sedana dikatakan sebagai mitologi karena tokoh yang ditampilkan adalah tokoh Dewa-Dewi yang memiliki kekuatan adimanusia berikut dengan setting atau latar cerita dikisahkan di Surga tempat para Dewa-Dewi.

Dalam Geguritan Sri Sedana dikisahkan Dewa Siwa sebagai penguasa alam Surga dan dunia fana, pada suatu hari Dewa Siwa mengadakan pertemuan dengan para Dewa-Dewi untuk menberikan umat manusia hadiah berupa benih yang dapat dimakan, selain dari singkong yang telah menjadi makanan pokok manusia ketika itu. Selesai pertemuan tersebut Dewa Siwa kemudian melakukan meditasi, tidak berselang lama muncul sebiji bibit berwarna kuning, Dewa Siwa bersabda agar bibit tersebut dibawa ke dunia untuk kesejahteraan umat manusia. Selesai bersabda berhembus angin kencang yang membawa bibit tersebut jatuh ke Bumi, para Dewa mengejar ke arah jatuhnya bibit tersebut, sesampainya di Bumi bibit anugrah Dewa Siwa telah dimakan oleh Naga Anantaboga.

Mengetahui bibit telah dimakan oleh Naga Anantaboga para Dewa meminta agar Naga bersedia mengembalikan biji bibit yang ditujukan untuk kemakmuran umat manusia. Naga Anantaboga berkenan memuntahkan bibit yang telah ditelan, namun terjadi hal yang tidak terduga dimana biji bibit yang dikeluarkan telah berubah menjadi seorang anak laki-laki dan seorang perempuan. Kejadian itu kemudian dilaporkan kehadapan Dewa Siwa, tanpa berfikir panjang beliau bersedia mengangkat kedua anak itu menjadi anak angkatnya. Anak laki-laki diberikan nama Dewa Sedana sedangkan anak perempuan bernama Dewi Sri.

Berselang beberapa tahun kedua anak angkat Dewa Siwa telah tumbuh dewasa menjadi lakilaki tampan dan perempuan cantik. Setelah mereka tumbuh remaja diceritakan Dewa Sedana dan Dewi Sri menjalin hubungan asmara yang terlarang, mengetahui hal tersebut Dewa Siwa murka dan ingin memutuskan jalinan hubungan mereka dengan berbagai cara, ketika tengah malam diceritakan Dewa Sedana dan Dewi Sri ditemukan sedang tidur berdua dalam satu kamar layaknya suami istri, Dewa Siwa kemudian menyeret Dewa Sedana sampai ke hutan larangan dan memerintahkan Dewa Sedana untuk memutuskan hubungan asmara dengan saudarinya Dewi Sri. Keinginan Dewa Siwa tidak dituruti oleh anak angkat beliau sehingga menimbulkan kemarahan Dewa Siwa seketika itu Dewa Siwa membakar Dewa Sedana menjadi abu.

Dewa Siwa memerintahkan Dewa Wara dan Wari untuk membuang mayat Dewa Sedana ke bumi yang telah ditutupi oleh peti, dari mulut Dewa Sedana keluarlah burung cetrung, tubuhnya berubah menjadi ular piton, adapun petinya berubah menjadi Belut, Katak dan Siput. Keesokan paginya ketika Dewi Sri terbangun, Dewi Sri tidak menemukan kakaknya, beliau mencari keseluruh ruangan sampai sore hari kemudian membuat sebuah hiburan dengan melubangi bambu yang dapat berbunyi nyaring ketika tertiup angin yang disebut dengan Sunari.

Melihat Dewi Sri sangat gigih mencari kakaknya, Dewa Wara merasa terharu dan memberitahu bahwa kakaknya telah menjadi abu (mati) dan dibawa ke dunia. Dewi Sri kemudian menghadap Dewa Siwa dan bertanya kenapa membunuh kakaknya dan apa yang menjadi penyebab Dewa Sedana dibunuh, Dewa Siwa kemudian menjawab prihal terbunuhnya Dewa Sedana karena menjalin hubungan asmara dengan adiknya sendiri. Mengetahui hal tersebut Dewi Sri meminta Dewa Siwa untuk membunuh juga dirinya karena telah berbuat hal yang sama dengan Dewa Sedana selain dari Dewi Sri sangat mencintai kakaknya. Mendengar perkataan Dewi Sri, Dewa Siwa sangat murka kemudian membakar Dewi Sri dengan matanya dan membuang mayat Dewi Sri ke dunia berikut dengan sunari yang telah dibuatnya.

Diceritakan di suatu Desa hidup dua pasangan suami istri yang telah lanjut usia yaitu Kakek Patuk dan Nini Patuk dimana kegiatan hariannya setiap pagi pergi ke hutan mencari singkong dan keladi untuk dimakan. Pada suatu pagi ketika kedua pasangan tua menuju hutan untuk singkong dan keladi mereka melihat mayat Dewi Sedana, kemudian Kakek Patuk dan Nini Patuk membuat lubang untuk menguburkan Dewi Sri sambil Nini Patuk membuat upakara untuk upacara kematian Dewi Sri yang sangat sederhana. 
Setelah prosesi upacara kematian berlangsung dari kuburan Dewi Sri muncul suatu tanaman yang aneh berwarna hijau mereka sangat terkejut terhadap kejadian tersebut, ketika itu Dewa Siwa muncul dan bersabda kepada Kakek Patuk dan Nini Patuk untuk membuka lahan di suatu tempat yang memiliki curah hujan yang cukup, tempat itu akan menjadi sawah serta memelihara tanaman padi tersebut untuk kesejahteraan keturunannya dikemudian hari.

Sabda Dewa Siwa dilanjutkan dengan menasehati keturunan Kakek Patuk dan Nini Patuk prihal bahayanya menjual atau merusak tanah persawahan karena akan membawa bencana bagi alam serta bagi kehidupan keturunannya dikemudian hari, maka diharuskan tetap melestarikan tanah sawah dan tanah sawah lahan kering selain juga demi kelangsungan hidup dalam hal ini kebertahanan pangan dan kehidupan juga untuk mempertahankan kebiasaan-kebiasaan (tradisi) yang telah dilakukan oleh leluhur.

\subsection{Relasi Kuasa Dalam Mitos Padi}

Mitos Padi dalam Geguritan Sri Sedana menggunakan tokoh Dewa-Dewi sebagai tokoh utama yang memiliki kekuatan melebihi manusia biasa. Menurut Mauss ${ }^{4}$ dalam suatu cerita atau mitos Dewa-Dewa selalu memiliki status yang lebih tinggi dari umat manusia, hal ini terjadi karena pemberian Para Dewa begitu berharga sehingga manusia tidak mampu membalas dengan sesuatu yang sepadan. Terkait dengan pendapat ahli di atas Hicks ${ }^{5}$ menjelaskan dalam suatu cerita atau mitos anugrah yang diberikan oleh para Dewa kepada manusia adalah berupa kehidupan, kesuburan dan keberlimpahan.

Dewa Siwa adalah salah satu tokoh yang terdapat dalam Geguritan Sri Sedana. Setiap tokoh dalam cerita suatu karya sastra menurut Abrams $^{6}$ memiliki moralitas, kepribadian dan

\footnotetext{
4 Mauss, Marcel. 1990. The Gift: Bentuk dan alasan Pertukaran Sosial Kuno. dalam "Ekofeminisme Tafsir Agama, Pendidikan, Ekonomi dan Budaya” (Editor: Dewi Candraningrum). Yogyakarta: Jalasutra.

5 Hicks, David. 2007. Younger Brother and Fishing Hook in Timor. dalam "Ekofeminisme Tafsir Agama, Pendidikan, Ekonomi dan Budaya" (Editor: Dewi Candraningrum). Yogyakarta: Jalasutra

6 Abrams, M.H. 1988. Glossary of Litterasy Term (edisi ketujuh)
}

emosi sehingga dapat melihat karakteristik tokoh-tokoh dalam cerita untukmengungkapkan relasi antar tokoh laki-laki dan perempuan dalam membongkar kerangka berfikir dan tindakan.

Relasi antara laki-laki dan perempuan tidak bisa dilepaskan dari gagasan yang ada dibaliknya, yakni ideologi gender, ideologi patriarki dan ideologi seks ${ }^{7}$. Ketiga ideologi tersebut membentuk tindakan, perkataan (bahasa), dan segala bentuk realisasi di berbagai media. Menurut Takwin ${ }^{8}$ oleh karena ideologi merupakan salah satu bentuk ketidaksadaran, maka praktiknya dalam diri manusia tidak disadari, ideologi masuk lewat berbagai sumber yang terkait dengan struktur masyarakat. Sesuai dengan pandangan tersebut menarik untuk disimpulkan tentang relasi kuasa yang terangkum dalam istilah ideologi dimana menurut Thompson ${ }^{9}$ ideologi adalah sistem berfikir, sistem kepercayaan, praktik-praktik simbolik yang berhubungan dengan tindakan sosial dan politik.

Berdasarkan Sinopsis di atas Dewa Siwa menciptakan satu bibit yang kemudian menjadi sepasang anak buncing, bila dikaitkan dengan gagasan Fromm ${ }^{10}$ hal ini menunjukan hilangnya peran dasar alamiah perempuan yang digantikan oleh laki-laki yaitu penciptaan lewat pikiran, yang tidak membutuhkan substansi hidup maternal. Secara hermeneutik bibit merupakan hasil dari pembuahan atau insemenisasi namun dilakukan oleh Dewa Siwa sendiri, sedangkan bibit yang di hembuskan oleh angin dan dimakan oleh Naga Ananta Boga sebagai pengganti rahim untuk melahirkan, pandangan tersebut sesuai dengan gagasan Dananjaya ${ }^{11}$

Penggantian rahim oleh mantra, Yoga, Api

. Jatinagor: Universitas Padjajaran

7 Atmaja, Nengah Bawa. 2010. Komodifikasi Tubuh Perempuan Bali : Joged Ngebor Bali. Denpasar: Program Studi Magister dan Doktor Kajian Budaya Universitas Indonesia bekerja sama dengan Pustaka Larasan.

8 Takwin, Bagus. 2003. Akar-Akar Ideologi. Yogyakarta: Jalasutra

9 Thompson, J.B.2003. Analisis Ideologi Kritik Wacana Ideologiideologi Dunia (Haqqul Yaqin penerjemah). Yogyakarta: IRCiSoD.

10 Fromm, Erich. 2011. Cinta, Seksualitas dan Matriarki. Yogyakarta: Jalasutra.

11 Dananjaya, Ida Bagus Made Satya Wira. 20014. Mengarah ke Patriarki. (dalam Majalah Raditya Edisi Juli 2014. No. 204. Hal 40-41. Denpasar: Manikgni. 
persembahan atau yang lainnya terdapat diberbagai mitos di hampir seluruh kebudayaan di Dunia yang dapat diartikan sebagai kecemburuan laki-laki kepada perempuan karena tidak memiliki fungsi prokreasi atau melahirkan yang dimiliki oleh perempuan. Peran prokreasi secara alamiah hanya dimiliki oleh perempuan, melahirkan anak, membesarkan anak yang menurut kaum naturalistik disamakan dengan peran bumi (sebagai Ibu), yang dapat menghasilkan tumbuhtumbuhan dan berbagai hasil tanaman yang sangat berguna bagi kehidupan manusia. Hanya perempuan yang secara alamiah melalui rahimnya melahirkan anak, begitu juga hanya di Bumi, tumbuhan yang penting bagi manusia dapat tumbuh dan berkembang, tegasnya lakilaki cemburu akan peran penting yaitu mencipta.

Bila merujuk pada pandangan tersebut di atas, mulai dari proses penciptaan benih dan pergantian rahim menunjukan secara psikis pengambil alihan peran alamiah perempuan yaitu penciptaan, atau Fromm ${ }^{12}$ menyatakan adanya indikasi dari keirihatian laki-laki terhadap perempuan dari perasaan inferioritas karena ketidakmampuannya melahirkan, dan dari hasratnya untuk memperoleh kemampuan ini. Selain itu tokoh Dewa Siwa sebagai laki-laki dalam relasinya dengan tokoh Dewi Sri sebagai perempuan terdapat suatu gagasan tentang hubungan bertingkat dimana tokoh Dewa Siwa adalah yang tertinggi posisinya atau dominan, hal tersebut terlihat dari episode pemberian wahyu atau biji. Dalam pemberian atau penganugrahan wahyu melibatkan tiga tokoh penting antara lain: 1) Dewa Siwa yang bertugas memberi wahyu, 2) Wahyu itu sendiri yaitu berupa biji untuk bibit penjelmaan Dewi Sri, 3) dan tokoh penerima wahyu, yang diberikan anugrah. Hubungan ketiga tokoh tersebut terbangun secara vertikal, artinya pihak pemberi anugrah memiliki posisi dengan strata yang lebih tinggi dibandingkan dengan pihak penerima wahyu atau wahyu itu sendiri.

\subsection{Idealitas yang Seksis}

Tokoh atau pihak pemberi wahyu dalam (Geguritan Sri Sedana) yaitu Dewa Siwa sebagai

12 Fromm, Erich. 2011. Cinta, Seksualitas dan Matriarki. Yogyakarta: Jalasutra. pihak yang superior, karena merupakan raja Dewa yang memiliki kuasa. Dewa Siwa sebagai penguasa berhak membuat keputusan mutlak, otoriter, dan harus dianut oleh pihak yang memiliki strata dibawahnya. Menurut Warren (dalam Suryaningsih, 2013) ${ }^{13}$ salah satu karakteristik yang jelas dari karya sastra dengan kerangka pikir patriarki adalah pola pikir yang berdasarkan nilai hierarkis yaitu yang merujuk pada "atas-bawah" yang memberikan nilai, status ataupun prestise yang lebih tinggi terhadap segala sesuatu yang berada di atas.

Tokoh kedua yaitu Dewi Sri yang telah berubah menjadi biji tanaman hijau, dimana tokoh ini posisinya lebih rendah dari pemberi anugrah, menurut analisis Paz ${ }^{14}$ Dewi Sri sebagai wahyu atau anugrah berada pada tokoh "ambang" atau diantara dan lebih rendah dari tokoh dominan. Tokoh yang ketiga adalah penerima wahyu yang menduduki posisi yang paling bawah, karena hanya dapat menerima, namun tidak dalam kondisi subordinasi, karena pihak penerima wahyu adalah orang yang terpilih, khusuk dalam bekerja, mengolah tanah, dan melakukan yajnya.

Sesuai dengan data di atas penerima wahyu merupakan pihak yang rajin dalam mengolah tanah, bahkan sampai pada usia kakek-nenek, selain itu melihat mayat Dewi Sri kakek patuk dan nenek patuk ingin menguburkan serta memberikan suatu upacara yajnya kecil. Lebih lanjut dalam episode dihukumnya Dewa Sedana dan Dewi Sri karena melakukan hubungan sedarah, bila menitik beratkan pada tokoh Dewa Siwa dan Dewi Sri terdapat kerangka berfikir sebagai berikut dominasi.

Dualisme nilai, misalnya pasangan yang berbeda dipandang sebagai oposisi (dan bukannya melengkapi) dan ekslusif (bukan inklusif), dan yang menempatkan nilai (status dan prestise) kepada salah satu dari suatu pasangan gagasan dari pada yang lain (Warren, dalam Suryaningsih, 2013) ${ }^{15}$.

13 Suryaningsih, Ervin. 2013. Kendali Patriarki atas Perempuan dan Alam dalam Cerpen Kering (2006) Karya Wa Ode Wulan Ratna: Sebuah Kajian Ekofeminisme. Dalam "Ekofeminisme dalam Tafsir Agama, Pendidikan, Ekonomi dan Budaya" hal 31-41 (Editor: Dewi Candraningrum). Yogyakarta: Jalasutra.

14 Paz, Octavio. 1995. Levi-Strauss Empu Antropologi Strukrural. (Landung Simatupang:Penerjemah). Yogyakata: LKis.

15 Suryaningsih, Ervin. 2013. Kendali Patriarki atas Perempuan dan Alam dalam Cerpen Kering (2006) Karya Wa Ode Wulan 
Pendapat ahli di atas menunjukan adanya suatu gagasan dualisme yang mana pihak yang diberikan nilai, status serta prestise yang tinggi kepada apa yang secara historis diidentifikasi sebagai pikiran, nalar, logika adalah laki-laki atau dalam konteks ini adalah Dewa Siwa, sedangkan Dewi Sri (dan juga Dewa Sedana) diidentifikasi secara historis sebagai tubuh, perasaan, dan keterikatan badaniah. Dewa Siwa dilukiskan sebagai sosok yang menggunakan akal sehat, nalar, melawan Dewi Sri yang menggunakan Perasaan dan keterikatan badaniah.

Berdasarkan hal tersebut menarik untuk meminjam gagasan Capra $^{16}$ gejala ini bisa dikaitkan dengan dualisme kultural, yakni wanita intuitif, sedangkan pria adalah rasional, maka terdapat sebuah legitimasi oleh Dewa Siwa untuk menghukum Dewi Sri. Jadi dapat dikatakan Dewa Siwa sebagai pihak laki-laki

Ratna: Sebuah Kajian Ekofeminisme. Dalam "Ekofeminisme dalam Tafsir Agama, Pendidikan, Ekonomi dan Budaya" hal 31-41 (Editor: Dewi Candraningrum). Yogyakarta: Jalasutra.

16 Capra, Fritjof. 2000. Titik Balik Peradabab Sains, Masyarakat dan Kebudayaan. (M Thoyibi Penerjemah). Yogyakarta: Benteng Budaya. telah dimaskulinisasi melalui pemikiran yang logis dan kritis sedangkan Dewi Sri merupakan pihak yang diintuitifkan atau difeminimkan. Jadi tidak salah menurut pandangan Basharat (2009) mitos keagamaan cenderung sangat male-dominated dan tidak memberi penghargaan sama sekali terhadap perempuan.

\section{Kesimpulan}

Setelah analisis data pada bab-bab sebelumnya, ada suatu temuan yang menyimpulkan bahwa mitos munculnya padi dengan tokoh Dewi Sri dan Dewa Siwa sebagai tokoh utama memiliki suatu relasi kekuasaan yang timpang dimana terdapat asumsi ideologi gender dan ideologi seks. Ideologi gender mengungkapkan adanya suatu perbedaan sosial peran laki-laki dan perempuan dalam kehidupan sosial dimana kedudukan laki-laku lebih tinggi dari kehidupan sosial. Sedangkan ideologi seks mengungkapkan adanya suatu tirani abadi terhadap konstruksi perempuan sebagai mahluk intuitif sedangkan laki-laki sebagai mahluk rasional.

\section{DAFTAR PUSTAKA}

Abrams, M.H. 1988. Glossary of Litterasy Term (edisi ketujuh) . Jatinagor: Universitas Padjajaran Arivia, Gadis. 2003. Filsafat Berperspektif Feminis. Jakarta: Yayasan Jurnal Perempuan.

Atmaja, Nengah Bawa. 2010. Komodifikasi Tubuh Perempuan Bali : Joged Ngebor Bali. Denpasar: Program Studi Magister dan Doktor Kajian Budaya Universitas Indonesia bekerja sama dengan Pustaka Larasan.

Capra, Fritjof. 2000. Titik Balik Peradabab Sains, Masyarakat dan Kebudayaan. (M Thoyibi Penerjemah). Yogyakarta: Benteng Budaya.

Dananjaya, Ida Bagus Made Satya Wira. 20014. Mengarah ke Patriarki. (dalam Majalah Raditya Edisi Juli 2014. No. 204. Hal 40-41. Denpasar: Manikgni.Mariasusai Dhavamony. 1995. Fenomenologi Agama. Yogyakarta: Kanisius

Fromm, Erich. 2011. Cinta, Seksualitas dan Matriarki. Yogyakarta: Jalasutra.

Hicks, David. 2007. Younger Brother and Fishing Hook in Timor. dalam "Ekofeminisme Tafsir Agama,

Pendidikan, Ekonomi dan Budaya" (Editor: Dewi Candraningrum). Yogyakarta: Jalasutra

Mauss, Marcel. 1990. The Gift: Bentuk dan alasan Pertukaran Sosial Kuno. dalam "Ekofeminisme

Tafsir Agama, Pendidikan, Ekonomi dan Budaya" (Editor: Dewi Candraningrum). Yogyakarta: Jalasutra. 
Paz, Octavio. 1995. Levi-Strauss Empu Antropologi Strukrural. (Landung Simatupang:Penerjemah). Yogyakata: LKis.

Ritzar, George dan Goodman Douglas, J. 2004. Teori Sosiologi Modern. Jakarta : Prenada Media.

Suryaningsih, Ervin. 2013. Kendali Patriarki atas Perempuan dan Alam dalam Cerpen Kering (2006) Karya Wa Ode Wulan Ratna: Sebuah Kajian Ekofeminisme. Dalam "Ekofeminisme dalam Tafsir Agama, Pendidikan, Ekonomi dan Budaya" hal 31-41 (Editor: Dewi Candraningrum). Yogyakarta: JalasutraTakwin, Bagus. 2003. Akar-Akar Ideologi. Yogyakarta: Jalasutra

Thompson, J.B.2003. Analisis Ideologi Kritik Wacana Ideologi-ideologi Dunia (Haqqul Yaqin penerjemah). Yogyakarta: IRCiSoD. 